\title{
Mobile learning in dentistry: Usage habits, attitudes and perceptions of undergraduate students
}

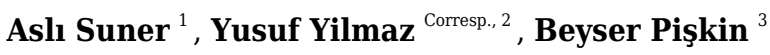 \\ ${ }^{1}$ Department of Biostatistics and Medical Informatics / Faculty of Medicine, Ege University, İzmir, Turkey \\ 2 Department of Medical Education / Faculty of Medicine, Ege University, İzmir, Turkey \\ 3 Division of Endodontology / School of Dentistry, Ege University, İzmir, Turkey \\ Corresponding Author: Yusuf Yilmaz \\ Email address: yusuf.yilmaz@ege.edu.tr
}

Introduction. The aim of this study was to evaluate usage habits, attitudes and perceptions towards mobile learning (m-learning), as well as to identify variables related to those attitudes amongst undergraduate dental students.

Materials and Methods. The study consists of 81 dental undergraduate students who who volunteered to participate. The data collection tool consists of an m-learning attitude scale, a questionnaire, and open-ended questions. To compare the total scores and factors of m-learning attitude scale for demographic information and mobile technology usage habits of the students; Mann-Whitney $U$ test was used for two independent groups such as gender, presence of electronic devices, and places of Internet usage. Kruskal-Wallis test was also used to compare the total scores and factors of m-learning attitude scale for more than two independent groups including internet usage purposes and opinions. Spearman's correlation coefficient was performed, and linear regression analysis was used to predict the change in total score according to the purposes of Internet usage.

Results. The majority of students thought that the use of mobile devices in dentistry courses was useful and their attitudes towards m-learning were high. The students generally use the Internet for online shopping, connecting to social networks, and communication. They tend to use mobile technologies for personal use, followed by educational purposes. There were significant differences found in the $\mathrm{m}$ learning attitudes for gender, having a portable power supply and use of mobile devices in dentistry courses. Communication was found significant in predicting the change in total score for the m-learning attitude scale according to the purpose of Internet usage.

Conclusion. Dental students have generally positive attitudes towards m-learning. Students raise awareness towards the promise of m-learning in order to apply their individual technology use and learning behaviours. Designing learning materials and applications for mobile devices may increase students' performances. 


\section{Mobile learning in dentistry: Usage habits, attitudes and perceptions of 2 undergraduate students}

3 Aslı Suner ${ }^{1}$, Yusuf Yilmaz ${ }^{2}$, Beyser Pişkin ${ }^{3}$

5 'Department of Biostatistics and Medical Informatics, Faculty of Medicine, Ege University, 6 İzmir, Turkey.

7 2Department of Medical Education, Faculty of Medicine, Ege University, İzmir, Turkey.

8 3 Division of Endodontology, School of Dentistry, Ege University, Izmir, Turkey

10 Corresponding Author:

11 Yusuf Yilmaz

Email address: yusuf.yilmaz@ege.edu.tr

\section{Abstract}

15 Introduction. The aim of this study was to evaluate usage habits, attitudes and perceptions towards mobile learning (m-learning), as well as to identify variables related to those attitudes

17 amongst undergraduate dental students.

18 Materials and Methods. The study consists of 81 dental undergraduate students who who

19 volunteered to participate. The data collection tool consists of an m-learning attitude scale, a

20 questionnaire, and open-ended questions. To compare the total scores and factors of m-learning

21 attitude scale for demographic information and mobile technology usage habits of the students;

22 Mann-Whitney $\mathrm{U}$ test was used for two independent groups such as gender, presence of

23 electronic devices, and places of Internet usage. Kruskal-Wallis test was also used to compare

24 the total scores and factors of m-learning attitude scale for more than two independent groups

25 including internet usage purposes and opinions. Spearman's correlation coefficient was 
26 performed, and linear regression analysis was used to predict the change in total score according

27 to the purposes of Internet usage.

28 Results. The majority of students thought that the use of mobile devices in dentistry courses was

29 useful and their attitudes towards m-learning were high. The students generally use the Internet

30 for online shopping, connecting to social networks, and communication. They tend to use mobile

31 technologies for personal use, followed by educational purposes. There were significant

32 differences found in the m-learning attitudes for gender, having a portable power supply and use

33 of mobile devices in dentistry courses. Communication was found significant in predicting the

34 change in total score for the m-learning attitude scale according to the purpose of Internet usage.

35 Conclusion. Dental students have generally positive attitudes towards m-learning. Students raise

36 awareness towards the promise of m-learning in order to apply their individual technology use

37 and learning behaviours. Designing learning materials and applications for mobile devices may

38 increase students' performances.

39 Keywords. Dental students, Mobile learning, Attitudes, Dental education, Mobile technology

40 use

\section{Introduction}

42 Since Mattheos et al. (2008) first identified information technology (IT) related activities for use

43 in dental education, technology has increasingly developed, both in terms of hardware and

44 software applications. The use of mobile technologies in daily life has become widespread, and

45 equally, educational technologies have taken advantage of this opportunity. Learning

46 environments can be supported with the help of mobile technologies such as smartphones, tablet

47 computers and laptop computers (Elçiçek \& Bahçeci, 2017). Specifically, learning on mobile 
48 devices, which is termed as mobile learning (m-learning) is defined as the use of mobile

49 technologies in educational activities (Sharples, 2013; Stone, 2004; Winters, 2006). Learning

50 through mobile devices can be achieved ubiquitously, through the provision of instant access to

51 information (Sharples, 2000). Results of m-learning research emphasize that educational

52 activities lead to more meaningful learning where learning contents are designed appropriately

53 according to learners’ interests and needs (Elçiçek \& Bahçeci, 2017).

54 There are multiple advantages that m-learning brings to education. First of all, since educational

55 programmes loaded with time-intensive and knowledge-intensive courses are becoming more

56 and more difficult for students to prepare for each lecture, the efficiency of such programmes

57 become critically affected (Harvey, Rothman, \& Frecker, 2003). Second, whilst it is possible for

58 students to withstand intensive course content delivery over a short period of time, prolonged

59 instruction at this intensity may make meaningful learning more difficult (Van Merriënboer \&

60 Sweller, 2010). Third, in education programmes where Internet technologies are used, solutions

61 are introduced that employ various approaches. The widespread usage of mobile technologies

62 today makes m-learning even more prominent. However, each student's access to mobile

63 technologies, and their level and purpose of usage may of course differ. With a general 'Bring

64 Your Own Device' (BYOD) policy in higher education, m-learning activities are reliant upon

65 usage of technology equipment owned by the students (Hwang, Lai, \& Wang, 2015; Song,

66 2014). In particular, knowing what kind of tools and usage habits students have, and then

67 designing educational activities accordingly can go some way to the provision of equal

68 opportunities in education (Şahin \& Başak, 2017). Last but not least, the perspectives of students

69 towards educational activities with such technologies can significantly affect their attitudes

70 towards learning (Yağc1, 2017). 
71 Nowadays, most dental students are from Generation Z. Although this generation was born into

72 technology and with technological devices very much a part of their daily life; it does not

73 necessarily mean that they can or want to learn with and on mobile devices (Khatoon, Hill, \&

74 Walmsley, 2014; The Center for Generational Kinetics, 2018). Therefore, it is important to

75 understand dental students' attitudes and opinions towards m-learning.

76 Use of mobile technologies has dramatically increased in the last decade (Fu \& Hwang, 2018).

77 M-learning has attracted attention in many fields such as engineering (Humanante-Ramos,

78 García-Peñalvo, \& Conde-González, 2017), teacher education (Dashtestani, 2016), and business

79 management (Al-Emran, Elsherif, \& Shaalan, 2016). Mobile technologies are also seen as

80 increasingly preferred for use by researchers in health sciences including medicine,

81 pharmacology, and nursing in order to educate students as well as communication for the

82 purposes of consultation and for accessing scientific research in support of patient care (Al-

83 Emran et al., 2016; Briz-Ponce, Juanes-Méndez, García-Peñalvo, \& Pereira, 2016; Cain, Bird, \&

84 Jones, 2008; Davies et al., 2012; Rodis, Aungst, Brown, Cui, \& Tam, 2016). While attitudes of

85 dental students are generally positive towards e-learning (Brumini et al., 2014), their attitudes

86 towards m-learning were not investigated to our knowledge. However higher education students

87 and medical students were included in previous studies to explore attitudes or perceptions

88 towards m-learning based on age, country, gender, smart-phone usage and class (Al-Emran et al.,

89 2016; Patil et al., 2016). Although dentistry-related mobile applications are becoming very

90 popular (Khatoon et al., 2014), less is known about the usage habits, attitudes, opinions of dental

91 students, or their perceptions and approaches to change in terms of m-learning. Thus, the

92 researchers of the current study believe that determining the mobile technology usage habits of 
93 undergraduate dental students, and examining their attitudes and perceptions towards m-learning

94 may contribute to the development of m-learning enabled educational programmes.

95 Therefore, the aim of the current study was to determine the mobile technology usage habits of

9681 undergraduate dental students and their attitudes and opinions towards m-learning in terms of

97 various variables. Specifically, the study objectives were as follows: (1) to describe usage of

98 mobile technology in dental students, (2) to explore students attitudes towards m-learning, and

99 (3) to explore the role of the students' demographic information, and the purpose and habits of

100 using mobile technologies as examined by previous research studies (Deshpande, Kalaskar, \&

101 Chahande, 2016; Khatoon et al., 2014; Rung, Warnke, \& Mattheos, 2014).

\section{Materials and Methods}

103 To address the aim of the study, a cross-sectional survey design, which is used to collect

104 information at a specific period of time (Fraenkel, Wallen, \& Hyun, 2014), was utilized. Ethics

105 committee approval was received from Ege University Scientific Research and Publication

106 Ethics Health Sciences Board with 04/17 reference number at 15 May 2018 prior to the study's

107 commencement.

\section{Sample}

109 The sample consisted of 81 undergraduate students, from $1^{\text {st }}$ to $5^{\text {th }}$ years, who volunteered to

110 participate to the study during the Spring Semester of the 2017-2018 Academic Year at Ege

111 University's Faculty of Dentistry, Turkey. Since all the population was intended to be reached,

112 no sampling method was determined or applied. 


\section{Instruments}

114 The data collection tool consisted of three parts, an m-learning attitude scale, a questionnaire, 115 and open-ended questions (Supplementary File 1).

116 1. M-Learning Attitude Scale: This scale, which was developed by Çelik (2013) and designed

117 as a five-point, Likert-type scale instrument, consists of 21 items, of which five are reverse-

118 scored items. The total score for the scale ranges from 21 to 105 . The higher the total score, the

119 greater the positive attitude towards m-learning. In order to determine the validity of the scale,

120 the Cronbach's alpha coefficient was calculated as 0.881 (Çelik, 2013). There are four factors in

121 the scale: 'Advantages of M-Learning (F1)', 'Limitations in M-Learning (F2)', 'Usability in M-

122 Learning (F3)', and 'Freedom in M-Learning (F4)'. There are five different response options

123 levels for each question: '5-Strongly Agree', '4-Agree', '3-Undecided', '2-Disagree', and '1-

124 Strongly Disagree'. In the current study, the Cronbach Alpha coefficient of the scale was

125 calculated as 0.886 , and the scale was found to be highly reliable.

126 2. Student Information Form: This questionnaire was prepared by the researchers based on

127 previous research studies in the literature, and contains a total of 11 questions based on the

128 respondent's demographic information (gender, year of birth, etc.) and their mobile technology

129 usage habits (presence of electronic devices, places of Internet usage, Internet usage purposes,

130 and opinions, etc.) in general (Deshpande et al., 2016; Khatoon et al., 2014; Rung et al., 2014).

131 3. Opinions about Mobile Learning: This part of the questionnaire consists of five open-ended

132 questions which the researchers of the study generated, and can be seen as below. Whilst not

133 obligatory to answer, the aim of these questions was to gather general views of the students

134 about m-learning. 
135 1. Are there any mobile phone applications that you use for training purposes? Please

136 indicate if applicable.

137 2. What are the positive aspects of course learning with mobile learning?

138 3. What are the negative aspects of course learning with mobile learning?

139 4. What are your expectations for the use of mobile tools in the processing of courses?

140 5. What kind of content do you want to see on mobile devices to increase your success in $141 \quad$ your courses?

\section{Data Collection and Analysis}

143 The data collection instruments were transferred to LimeSurvey which was used as an online

144 data collection system (LimeSurvey, 2018) for this study and placed on the faculty website for

145 the purposes of data collection

146 (https://okm.med.ege.edu.tr/anket/index.php? $\mathrm{r}=$ survey/index\&sid=468989). This weblink was

147 announced to the target student population via the Ege University Faculty of Dentistry Learning

148 Resources Centre, and students were asked to participate in the survey voluntarily. In addition,

149 since one of the researchers was a lecturer in the Faculty of Dentistry, and the other researcher

150 was the Dean of the Faculty, the survey was also verbally announced to the students and that

151 voluntary participation was anticipated. Moreover, announcements were made through student

152 communication groups (e.g., WhatsApp), and via student noticeboards located in the faculty.

153 With the consent form on the opening page of the online questionnaire, prospective participant

154 students were informed in more detail about the study and their consent to participate was

155 obtained. The data collected was stored within a secure database that was only accessible to the

156 researchers. The data collection process lasted for a period of two weeks. In order to increase 
157 participation in the study, announcements were repeated several times during the data collection 158 period.

159 While continuous variables were presented as median (min-max), categorical variables were

160 described with frequencies and percentages. Cronbach's alpha for the m-learning attitude scale

161 was calculated. Shapiro-Wilk normality test was used to examine whether the numerical data

162 were distributed normally. Since the data were not found to be normally distributed, to compare

163 the total scores and factors of m-learning attitude scale for demographic information and mobile

164 technology usage habits of the students, Mann-Whitney U test was used for two independent

165 groups such as gender, presence of electronic devices, and places of Internet usage. Kruskal-

166 Wallis test followed by Mann-Whitney U test was applied in order to see the post-hoc results of

167 pairwise comparisons was also used to compare the total scores and factors of m-learning

168 attitude scale for more than two independent groups including internet usage purposes and

169 opinions. Correlation analyses were performed using Spearman's correlation coefficient. A

170 stepwise linear regression analysis was used in order to construct a model that predicted the

171 change in total score of the scale according to purpose of Internet usage. A final model was

172 executed on all the variables for the purpose of Internet usage, and they were included together

173 in the model. A value of $P<.05$ was considered statistically significant. Statistical analyses were

174 performed using IBM SPSS version 25.0 statistical software for personal computers.

\section{Results}

176 The results of the study were presented in four sections. First, the overall m-learning attitudes of

177 the participant students were summarised. Second, demographic information, mobile technology

178 usage habits gathered from the student information form, and the total score from the m-learning 
179 attitude scale were described and compared. Next, significant variables were examined based on

180 each factor of the m-learning attitude scale. Third, Internet usage purposes were modelled in

181 order to predict how the m-learning attitudes of students changed. Finally, opinions of students

182 about m-learning were reported.

183 Attitudes of Dental Students toward M-Learning

184 The factors of the scale, 'Advantages of M-Learning', 'Limitations in M-Learning', 'Usability in

185 M-Learning', and 'Freedom in M-Learning' were examined. The results demonstrated that

186 students generally reported positive opinions in respect of m-learning. The median, minimum

187 and maximum values of the m-learning attitude scale factors and total score are presented in

188 Table 1. The mean scores of the factors were found to be high, and the mean total score of the 189 scale was $79.52 \pm 10.62$ which revealed that the dentistry students have a high attitude towards

190 m-learning.

191 Demographics and M-Learning Attitude

192 Of the 81 student participants, $55.6 \%(n=45)$ were female. The total score of the male

193 participants was found to be statistically significantly higher than that of the females $(P=0.025)$.

194 The average age of the students was 21.23 years \pm 1.56 .

195 The results showed that $97.5 \%(n=79)$ of the students had a smartphone, $23.5 \%(n=19)$ had a

196 tablet computer and $85.2 \%(n=69)$ had a laptop computer. There was no statistically significant

197 difference found for the overall scores ( $P=0.110, P=0.584, P=0.283$, respectively) among

198 smartphone, tablet, and laptop owners. In terms of their Internet connectedness, $98.8 \%$ of the

199 students $(n=80)$ had an average of $6.38 \pm 3.69$ GB Internet package. While $38.3 \%$ of the 81 
200 students $(n=31)$ carried a charger with them, $25.9 \%(n=21)$ had a portable power supply unit.

201 While there was no statistically significant difference found between the total scores of the scale

202 and those without chargers $(P=0.214)$, those with a portable power supply unit were found to

203 have statistically higher total scores than those who did not $(P=0.019)$.

204 In terms of their smartphone usage, $91.4 \%(n=74)$ of the students reported that they checked

205 their mobile phones when they woke up; while 97.5\% $(n=79)$ checked their mobile phones

206 before going to sleep. There was no statistically significant difference found between the total

207 scores of the students who checked their phone and those who did not when either they woke up

208 or before going to sleep $(P=0.060, P=0.837$, respectively).

209 For the students Internet access, $85.2 \%$ of the students $(n=69)$ accessed the Internet at home,

$21044.4 \%(n=36)$ accessed the Internet from their student dormitories, $79.0 \%(n=64)$ used the

211 Internet at school, 95.1\% $(n=77)$ reached the Internet using their mobile phone, $61.7 \%(n=50)$

212 accessed the Internet in cafe-restaurants, and 46.9\% $(n=38)$ used free public Wi-Fi Internet

213 sources for $4.49 \pm 2.29$ hours per day. There was no statistically significant difference found

214 between the overall scores of the scale in terms of Internet access locations $(P>0.05)$.

215 When the students were asked to list the purposes of their Internet usage, the distribution of

216 options from the greatest to the least were online shopping ( $n=17,22.1 \%)$, connecting to social

217 networks $(n=17,22.1 \%)$, communicating $(n=13,16.9 \%)$, watching videos $(n=7,9.1 \%)$,

218 listening to music $(n=7,9.1 \%)$, reading scientific articles $(n=4,5.2 \%)$, accessing course

219 materials $(n=4,5.2 \%)$, reading the news $(n=4,5.2 \%)$, checking e-mails $(n=2,2.6 \%)$, and

220 playing games $(n=2,2.6 \%)$. No statistically significant difference was found between the total

221 scores of the scale in terms of purposes of Internet usage $(P=0.233)$. 
222 With regards to their courses, $51.4 \%$ of the students $(n=39)$ responded that use of mobile

223 devices in their dentistry courses was deemed to be useful, while $35.5 \%(n=27)$ responded that

224 it was very useful. None of the students stated that it was not useful at all. A statistically

225 significant difference was found between the opinions of the students' usage of mobile devices in

226 the courses given in dentistry $(P<0.001)$. Pairwise comparisons were made in order to see the

227 post-hoc results, and statistically significant differences were found between the responses of

228 'undecided' and 'agreed', between 'undecided' and 'strongly agreed', and between 'agreed' and

229 'strongly agreed' ( $P=0.004 ; P<0.001 ; P=0.001$, respectively).

230 As can be seen in Table 2, participants' demographic information and mobile technology usage

231 habits were examined in terms of the m-learning attitude scale total scores. In Table 3, the score

232 of the second factor for males was found to be statistically significant and higher than that of the

233 females $(P=0.018)$.

234 Students who carried portable power supply units scored statistically higher in the third and

235 fourth factors of the scale compared to those who did not carry power supply units $(P=0.015$,

236 and $P=0.024$, respectively). There were statistically significant differences between the student

237 opinions for the use of mobile devices in dentistry courses in terms of the four factor scores

238 ( $P=0.020 ; P=0.009 ; P=0.003$; and $P<0.001$; respectively). According to the results of

239 pairwise comparisons, the score of all four factors for students who 'strongly agreed' were found

240 to be statistically significant and higher than students who 'agreed' or were 'undecided'

$241(P<0.05)$.

242 In Table 4, a statistically significant correlation was found between average daily Internet usage

243 time and the second factor of the m-learning attitude scale, which represents the perceived 
244 limitations of m-learning $(r=0.243 ; P=0.032)$. Similarly, a significant correlation was found to

245 exist between the age of dentistry students and the third factor of the m-learning attitude scale

246 named 'Usability in m-learning', and the total score of the scale $(r=0.291 ; P=0.010$, and

$247 \quad r=0.229 ; P=0.044$, respectively).

\section{Effects of Internet Usage Purposes on M-Learning}

249 A linear regression analysis was used to predict the change in total score according to the

250 purposes of Internet usage. Therefore, neither sociodemographic information nor mobile

251 technology usage habits of the students were used in the regression model. A stepwise linear

252 regression model (Table 5) included online shopping, connecting to social networks, watching

253 videos, reading scientific articles, accessing course materials, checking e-mails, reading the

254 news, communicating, listening to music, and playing games to predict the total score of the

255 scale, and had a squared multiple correlation coefficient $\left(R^{2}\right)$ of 0.268 . This result indicated that

$25627 \%$ of the variation in the total score of the m-learning attitude scale according to purposes of

257 Internet usage was explained by only one variable, 'communicating' $(P=0.021)$.

258 Opinions about M-Learning

259 Students were asked whether or not they have applications for educational purposes installed on

260 their mobile phones, and it was found that 28 out of the 81 students $(34.56 \%)$ used their devices

261 for educational purposes. Students indicated that their most frequently used applications for m-

262 learning were WhatsApp, YouTube, the Dental-lite, foreign language learning, and atlas of

263 anatomy. 
264 The students were asked about what the positive aspects of courses with m-learning were, and 31

265 of the 81 students $(38.27 \%)$ commented on different features. The most preferred aspects of m-

266 learning were defined as its practicality, and that it was perceived as entertaining, interactive,

267 easily accessible, and repeatable. One student highlighted m-learning daily usage as 'M-learning

268 allows me to better understand the lessons that I missed or hadn't understood at all. It helps me

269 to prepare for exams, and prevents me from carrying around heavy books', and another student

270 described m-learning as 'Practical, visual and instructive with animations'.

271 On the other hand, although the comments and total score of the m-learning attitude scale

272 showed that the students had a positive attitude toward m-learning; 30 students (37.04\%)

273 reported negative aspects as problems associated with the charging of smartphones,

274 distractibility, and Internet connectability problems. Most of the students mentioned issues

275 regarding distraction caused by mobile devices away from learning, with some students saying

276 that 'M-learning may be insufficient where topics are incomprehensible or further details are

277 required', 'Faculty readiness should be provided for the use of mobile devices in the classroom',

278 and 'M-learning may increase the time spent with technological devices. Lectures could become

279 less attractive in the classroom environment. In this regard, our instructors need to renew and

280 adapt their lessons for today's technology'. These students' approaches suggest that m-learning

281 readiness should be increased, not only on a technological level, but also within the instructional 282 designs.

283 When students were asked about their expectations for the use of mobile devices in dentistry

284 courses, the students were largely positive towards m-learning. A total of 26 students $(32.10 \%)$

285 reported that lectures presented with m-learning activities that utilised more visual materials like

286 videos, animations and photos, were more interesting than traditional forms of teaching with a 
287 whiteboard or through PowerPoint presentations. One of the students summarised different

288 features for m-learning as 'Easy to find a lesson, ability to transfer notes between devices,

289 motivating and with a good looking user interface, able to jot down and highlight content, does

290 not slow down your device, resources are open to multifaceted learning, not just based on

291 reading'. Additionally, students wanted to be able to study at any time with lecture videos or

292 slides that were uploaded to the Internet, and all kinds of documents related to the topics covered

293 on the course that are accessible using mobile devices at any time. Students are also willing to

294 take mobile quizzes in the classroom, and want to be able to take notes on the course materials

295 using their mobile devices.

296 When asked what kind of content the students wished to see on their mobile devices in order to

297 improve their course success, 28 of the students (34.57\%) responded stating courses such as

298 anatomy, dental anatomy and physiology should be supported visually with videos, photos, and

299 applications. The students mentioned a number of application ideas to support their studies

300 interactively such as quizzes, examples of previous exam questions and videos for exam

301 solutions, mobile games on dentistry, and practical applications in dentistry.

\section{Discussion}

303 Based on their responses, it can be seen that the students are willing and eager to use mobile

304 technologies. As the findings suggest, students use the Internet for an average of 4.49 hours per

305 day. The top three Internet communication tools most frequently used by the dentistry students

306 on their devices were online shopping (22.10\%), connecting to social networks $(22.10 \%)$, and

307 communicating $(16.90 \%)$. Therefore, the students tend to use mobile technologies for personal

308 use first, followed by educational purposes. The study's findings are similar to those of Gosper, 
309 Malfroy, and McKenzie (2013), and also Kukulska-Hulme and Pettit (2009) in which students'

310 usage of mobile technologies were described. In the study of Gosper, Malfroy, and McKenzie

311 (2013), they found that most of the students (over three-quarters) regularly use mobile phones for

312 personal use including text messaging, email, social networking, etc. Even though it is not used

313 as much personal use, the technologies for course related learning activities such as library

314 databases and journals also preferred. Kukulska-Hulme and Pettit (2009) also reported that

315 although $96 \%$ of the students use mobile phones for social interaction; very few of the students

316 used them for educational purposes (30\% for teaching; $\% 17$ for learning). A previous study also

317 revealed that the majority of students connect to the Internet on their mobile devices in order to

318 check e-mails (84\%) and to use social networks (79\%) (Khatoon et al., 2014). Since the ratio of

319 students with a laptop computer (85.20\%) was lower than for a smartphone (97.50\%), and almost

320 all of the students had mobile Internet packages $(98.80 \%)$, the students mostly preferred

321 smartphones for connecting to the Internet. Smartphones and laptops were shown to be popular

322 devices in the current study and in the study of Khatoon et al. (2014), students reporting usage of

323 a tablet computer $(23.50 \%)$ showed it to be the less popular electronic device. The results of a

324 study by Khatoon et al. (2014) suggested that smartphone usage may be greater than that of

325 computers due to the latter being more difficult and impractical to carry.

326 Students reported that they use certain applications for m-learning. The most preferred mobile

327 applications being WhatsApp, YouTube, the Dental-lite, foreign language learning, and atlas of

328 anatomy. With regards to mobile applications, similar results were found for dentistry students

329 from different countries (Chase et al., 2018; Deshpande et al., 2016; Khatoon et al., 2014; Rung

330 et al., 2014). Dictionary for dental education, applications with quizzes on various lectures such

331 as anatomy and chemistry, and visual tools in dental education were popular purposes for using 
332 m-learning applications. It has been recommended that applications developed for a variety of

333 patient cases could improve the clinical decision-making skills of dental students (Deshpande et

334 al., 2016). Sandholzer, Deutsch, Frese, and Winter (2016) also revealed that using m-learning

335 apps which are designed to support medical students' knowledge contributes to active student

336 learning. The students preferred to watch videos on YouTube for educational purposes from their

337 smartphones, a finding that was supported by a recent study where students found YouTube

338 videos more helpful than traditional teaching methods (Khatoon et al., 2014). Similarly, the

339 study of Botelho, Gao, and Jagannathan (2019) described how video learning supported the

340 knowledge transfer of students with novel learning opportunities.

341 A previous study showed that students preferred to use smartphones for learning purposes such

342 as taking photographic images of their work, organising timetables for courses, surfing the

343 Internet for other learning materials, and for checking course announcements (Rung et al., 2014).

344 In the study of Gilavand and Shooriabi (2016), it was found that smartphones could be used for

345 educational purposes; however, in various dental faculty curricula, m-learning has not yet been

346 utilised. It is suggested that each educational system could use mobile technologies with

347 appropriate suitable methods, activities and educational materials (Gilavand \& Shooriabi, 2016;

348 Taylor et al., 2010). Specifically, m-learning apps need to be specifically designed for

349 smartphones, as other mobile device types such as tablets may have several disadvantages based

350 on technological aspects and their usability (Chase et al., 2018).

351 The attitudes and views of the dental students are reportedly influenced by many factors. In the

352 study of Brumini et al. (2014), which aimed to measure attitudes towards e-learning amongst

353 dental students, the researchers revealed gender not to be a significant predictor. However, in

354 another study which investigated current knowledge, skills, and opinions of undergraduate dental 
355 students with respect to information communication technologies, the skills of male students

356 were found to be better than those of female students, and that they were more familiar in the use

357 of computers, and also longer users of computers (Rajab \& Baqain, 2005). Despite the study of

358 Brumini et al. (2014) and a similar study of Rajab and Baqain (2005), the m-learning attitude

359 scale's total score for males in the current study were found to be statistically significant and

360 higher than that of the females. Moreover, students with portable power supply units were found

361 to reveal statistically higher m-learning attitude scale total scores than those who did not carry

362 such units. The results revealed that students' attitudes using their mobile devices for longer

363 periods could be positively affected by this situation. This finding was also supported by Patil

364 et al. (2016) in whose study medical students showed the same interest as dental students.

365 Another statistically significant result was found on student opinions with regards to the use of

366 mobile devices in dentistry courses. The majority of students (86.9\%) thought that the use of

367 mobile devices in dentistry courses was useful and that their attitudes towards m-learning were

368 high. Similar to this result, the study of Deshpande et al. (2016) indicated that mobile

369 applications were helpful in learning different aspects of clinical dentistry, and mobile devices

370 could have a significant contribution to modern healthcare education. This result may be due to

371 teaching in dentistry using more visual materials, and therefore students' attitudes towards m-

372 learning in the current study were positive and showed them to be willing users of m-learning.

373 Analysis of the open-ended questions in the current study also confirmed students' perceptions in

374 using multimedia materials such as videos and animations.

375 There was a positive statistically significant correlation found between the average daily Internet

376 usage and the limitations of m-learning in the current study. Limitations of mobile devices such

377 as charging problems, small screen sizes, and the cost of mobile data significantly affected m- 
378 learning (Dashtestani, 2016; Humanante-Ramos et al., 2017; Winters, 2006). In addition, a

379 significant positive correlation was found to exist between dentistry students' ages and m-

380 learning usability, and the total score of the scale. The increased usage of mobile devices in

381 dentistry over recent years may explain the positive attitude. Similar to the current study's

382 results, a previous study (Brumini et al., 2014) showed that higher age demonstrated a significant

383 influence on positive attitudes towards e-learning.

384 A model constructed to predict the change in m-learning attitude scale total scores according to

385 the purpose of Internet usage showed that only communicating was found to be statistically

386 significant. This finding is consistent with the previous studies of Khatoon et al. (2014) and

387 Deshpande et al. (2016) who reported that although social networking and checking e-mails were

388 the most preferred types of communication, instant messaging on smartphones was just as

389 popular. In addition, students used mobile devices as a communication tool for sharing course

390 notes such as presentations, weblinks and photographic images of patients (Khatoon et al., 2014).

391 As a limitation of this study, we only focused on the usage habits, attitudes, perceptions, and

392 views of undergraduate dental students towards m-learning, regardless of its efficiency. The

393 faculty has Online Learning Resource Centre which students are able to access course contents

394 over a website of the centre. Therefore, students have experiences to use online resources for

395 educational purposes. We wanted to investigate how they use mobile devices for mobile

396 learning. The study also provides a potential mobile learning project in the future. Our study is

397 limited to one faculty and students from one academic year. Other dentistry faculties in Turkey

398 planning to use m-learning in their education programs may also be included in the new planned 399 studies. 
400 Conclusions

401 To the researchers' knowledge, this is the first study that examines usage habits, attitudes,

402 perceptions, and views of undergraduate dental students towards m-learning in Turkey.

403 According to the data analysis, dental students have generally positive attitudes towards m-

404 learning. They use mobile devices for various purposes and with different habits. The relation

405 between m-learning and mobile device usage was not found to differ significantly. The students

406 raise awareness towards the promises of m-learning in order to utilise their individual technology

407 usage and learning behaviours. Designing learning materials and applications for mobile devices

408 may increase students' overall performances on dental courses. The current study may be seen to

409 contribute to future novel studies relating to m-learning which as a developing need in the field

410 of dentistry education.

\section{Conflicts of Interest}

412 All authors declare no conflicts of interest.

\section{References}

414 Al-Emran, M., Elsherif, H. M., \& Shaalan, K. (2016). Investigating attitudes towards the use of mobile learning in higher education. Computers in Human Behavior, 56, 93-102. https://doi.org/10.1016/j.chb.2015.11.033

Botelho, M. G., Gao, X., \& Jagannathan, N. (2019). A qualitative analysis of students' perceptions of videos to support learning in a psychomotor skills course. European Journal of Dental Education, 23(1), 20-27. https://doi.org/10.1111/eje.12373

Briz-Ponce, L., Juanes-Méndez, J. A., García-Peñalvo, F. J., \& Pereira, A. (2016). Effects of Mobile Learning in Medical Education: A Counterfactual Evaluation. Journal of Medical Systems, 40(6), 136. https://doi.org/10.1007/s10916-016-0487-4 Attitudes towards e-learning amongst dental students at the universities in Croatia. 
426

427

428

429

430

431

432

433

434

435

436

437

438

439

440

441

442

443

444

445

446

447

448

449

450

451

452

453

454

455

456

457

458

459

460

Cain, J., Bird, E. R., \& Jones, M. (2008). Mobile Computing Initiatives Within Pharmacy Education. American Journal of Pharmaceutical Education, 72(4), 76. https://doi.org/10.5688/aj720476

Çelik, A. (2013). m-Learning Attitude Scale: Validity and Reliability Analyses. Journal of Research in Education and Teaching, 2(4), 172-185.

Chase, T. J. G., Julius, A., Chandan, J. S., Powell, E., Hall, C. S., Phillips, B. L., ... Fernando, B. (2018). Mobile learning in medicine: an evaluation of attitudes and behaviours of medical students. BMC Medical Education, 18(1), 152. https://doi.org/10.1186/s12909-018-1264-5

Dashtestani, R. (2016). Moving bravely towards mobile learning: Iranian students' use of mobile devices for learning English as a foreign language. Computer Assisted Language Learning, 29(4), 815-832. https://doi.org/10.1080/09588221.2015.1069360

Davies, B. S., Rafique, J., Vincent, T. R., Fairclough, J., Packer, M. H., Vincent, R., \& Haq, I. (2012). Mobile Medical Education (MoMEd) - how mobile information resources contribute to learning for undergraduate clinical students - a mixed methods study. $B M C$ Medical Education, 12(1), 1. https://doi.org/10.1186/1472-6920-12-1

Deshpande, S., Kalaskar, A., \& Chahande, J. (2016). Perceptions of faculty and students regarding use of mobile apps for learning in dentistry: A questionnaire based study. Journal of Education Technology in Health Sciences, 3(3), 128-130. Retrieved from http://jeths.net/index.php/jeths/article/view/132/112

Elçiçek, M., \& Bahçeci, F. (2017). The Investigation of the Effects of Mobile Learning Management System on Academic Success and Attitudes of Learners. Kastamonu Education Journal, 25(5), 1695-1714. Retrieved from http://79.123.169.199/ojs/index.php/Kefdergi/article/view/1081/586

Fraenkel, J., Wallen, N., \& Hyun, H. (2014). How to Design and Evaluate Research in Education. New York, NY: McGraw-Hill Education.

Fu, Q.-K., \& Hwang, G.-J. (2018). Trends in mobile technology-supported collaborative learning: A systematic review of journal publications from 2007 to 2016. Computers \& Education, 119, 129-143. https://doi.org/10.1016/j.compedu.2018.01.004

Gilavand, A., \& Shooriabi, M. (2016). Investigating the Impact of the Use of Mobile Educational Software in Increase of Learning of Dentistry Students. International Journal of Medical Research \& Health Sciences, 5, 191-197. Retrieved from www.ijmrhs.com

Gosper, M., Malfroy, J., \& McKenzie, J. (2013). Students' experiences and expectations of technologies: An Australian study designed to inform planning and development decisions. Australasian Journal of Educational Technology, 29(2). https://doi.org/10.14742/ajet.127

Harvey, B. J., Rothman, A. I., \& Frecker, R. C. (2003). Effect of an Undergraduate Medical

Peer] reviewing PDF | (2019:04:36994:1:0:NEW 14 Jun 2019) 
461

462

463

464

465

466

467

468

469

470

471

472

473

474

475

476

477

478

479

480

481

482

483

484

485

486

487

488

489

490

491

492

493

494

495

496

497

Curriculum on Students??? Self-Directed Learning. Academic Medicine, 78(12), 12591265. https://doi.org/10.1097/00001888-200312000-00015

Humanante-Ramos, P. R., García-Peñalvo, F. J., \& Conde-González, M. Á. (2017). Electronic Devices and Web 2.0 Tools: Usage Trends in Engineering Students. International Journal of Engineering Education (IJEE), 33(2B), 790-796. Retrieved from https://www.researchgate.net/publication/316139828

Hwang, G.-J., Lai, C.-L., \& Wang, S.-Y. (2015). Seamless flipped learning: a mobile technology-enhanced flipped classroom with effective learning strategies. Journal of Computers in Education, 2(4), 449-473. https://doi.org/10.1007/s40692-015-0043-0

Khatoon, B., Hill, K. B., \& Walmsley, A. D. (2014). Dental students' uptake of mobile technologies. British Dental Journal, 216(12), 669-673. https://doi.org/10.1038/sj.bdj.2014.523

Kukulska-Hulme, A., \& Pettit, J. (2009). Practitioners as innovators: Emergent practice in personal mobile teaching, learning, work and leisure. In M. Ally (Ed.), Mobile Learning: transforming the delivery of education and training. Issues in Distance Education (pp. 135155). Athabasca: Athabasca University Press. Retrieved from http://oro.open.ac.uk/15502/1/07_Mohamed_Ally_book_2009-Article7.pdf

LimeSurvey. (2018). An Open Source survey tool. Retrieved from https://www.limesurvey.org/about-limesurvey/license

Mattheos, N., Stefanovic, N., Apse, P., Attstrom, R., Buchanan, J., Brown, P., ... Walmsley, A. D. (2008). Potential of information technology in dental education. European Journal of Dental Education, 12(s1), 85-92. https://doi.org/10.1111/j.1600-0579.2007.00483.x

Patil, R. N., Almale, B. D., Patil, M., Gujrathi, A., Dhakne-Palwe, S., Patil, A. R., \& Gosavi, S. (2016). Attitudes and perceptions of medical undergraduates towards mobile learning (Mlearning). Journal of Clinical and Diagnostic Research, 10(10), JC06-JC10. https://doi.org/10.7860/JCDR/2016/20214.8682

Rajab, L. D., \& Baqain, Z. H. (2005). Use of information and communication technology among dental students at the University of Jordan. Journal of Dental Education, 69(3), 387-98. Retrieved from http://www.ncbi.nlm.nih.gov/pubmed/15749951

Rodis, J., Aungst, T. D., Brown, N. V, Cui, Y., \& Tam, L. (2016). Enhancing Pharmacy Student Learning and Perceptions of Medical Apps. JMIR MHealth and UHealth, 4(2), e55. https://doi.org/10.2196/mhealth.4843

Rung, A., Warnke, F., \& Mattheos, N. (2014). Investigating the Use of Smartphones for Learning Purposes by Australian Dental Students. JMIR MHealth and UHealth, 2(2), e20. https://doi.org/10.2196/mhealth.3120

Şahin, G., \& Başak, T. (2017). Mobile learning in nursing "m-learning. Journal of Human Sciences, 14(4), 4480-4491. https://doi.org/10.14687/jhs.v14i4.4891 
498

499

500

501

502

503

504

505

506

507

508

509

510

511

512

513

514

515

516

517

518

519

520

521

522

523

524

525

526

Sandholzer, M., Deutsch, T., Frese, T., \& Winter, A. (2016). Medical students' attitudes and wishes towards extending an educational general practice app to be suitable for practice: A cross-sectional survey from Leipzig, Germany. European Journal of General Practice, 22(2), 141-146. https://doi.org/10.3109/13814788.2016.1144746

Sharples, M. (2000). The design of personal mobile technologies for lifelong learning. Computers \& Education, 34(3-4), 177-193. https://doi.org/10.1016/S0360-1315(99)000445

Sharples, M. (2013). Mobile Learning: Research, Practice and Challenges. Distance Education in China, 3(5), 5-11. Retrieved from http://oro.open.ac.uk/37510/2/sharples.pdf

Song, Y. (2014). "Bring Your Own Device (BYOD)" for seamless science inquiry in a primary school. Computers \& Education, 74, 50-60. https://doi.org/10.1016/j.compedu.2014.01.005

Stone, A. (2004). Designing scalable, effective mobile learning for multiple technologies. In J. Attwell \& C. Savill-Smith (Eds.), Learning with mobile devices (pp. 145-153). London: Learning and Skills Development Agency. Retrieved from www.LSDA.org.uk

Taylor, J. D., Dearnley, C. A., Laxton, J. C., Coates, C. A., Treasure-Jones, T., Campbell, R., \& Hall, I. (2010). Developing a mobile learning solution for health and social care practice. Distance Education, 31(2), 175-192. https://doi.org/10.1080/01587919.2010.503343

The Center for Generational Kinetics. (2018). Generational Breakdown: Info About All of the Generations - GEN HQ. Retrieved January 31, 2019, from https://genhq.com/generation-zresearch-2018/

Van Merriënboer, J. J. G., \& Sweller, J. (2010). Cognitive load theory in health professional education: design principles and strategies. Medical Education, 44(1), 85-93. https://doi.org/10.1111/j.1365-2923.2009.03498.x

Winters, N. (2006). What is mobile learning? In M. Sharples (Ed.), Big Issues in Mobile Learning (pp. 5-9). Nottingham: University of Nottingham. Retrieved from http://matchsz.inf.elte.hu/tt/docs/Sharples-20062.pdf

Yağc1, M. (2017). Examining the Attitudes of Preservice Teachers Toward Mobile Learning in Terms of Technopedagogical Content Knowledge. Mehmet Akif Ersoy University Journal of Education Faculty, 44, 543-563. https://doi.org/10.21764/maeuefd.295244 


\section{Table 1 (on next page)}

M-Learning Attitude Scale Factors and Total Score 


\section{Table 1. M-Learning Attitude Scale Factors and Total Score}

\begin{tabular}{lccc}
\hline Factors & Median & Min-Max & Original Scale Min-Max \\
\hline F1: Advantages of M-Learning & 26.00 & $14.00-35.00$ & $7.00-35.00$ \\
F2: Limitations in M-Learning & 17.00 & $5.00-25.00$ & $5.00-25.00$ \\
F3: Usability in M-Learning & 20.00 & $13.00-25.00$ & $5.00-25.00$ \\
F4: Freedom in M-Learning & 16.00 & $11.00-20.00$ & $4.00-20.00$ \\
Total Score & 79.00 & $58.00-101.00$ & $21.00-105.00$ \\
\hline
\end{tabular}

2 
Table 2 (on next page)

Demographic information and mobile technology usage habits of the students 
1 Table 2. Demographic information and mobile technology usage habits of the students in 2 terms of the m-learning attitude scale total scores

\begin{tabular}{|c|c|c|c|c|}
\hline \multicolumn{2}{|l|}{ Variable } & \multirow{2}{*}{$\begin{array}{l}\boldsymbol{n}(\mathbf{\%}) \\
45(55.60)\end{array}$} & \multirow{3}{*}{$\begin{array}{l}\text { Total Score } \\
\text { Median (Min-Max) } \\
78.50(61.00-92.00) \\
82.50(62.00-101.00)\end{array}$} & \multirow{3}{*}{$\begin{array}{l}\boldsymbol{P} \text {-value } \\
0.025^{\mathrm{a}}\end{array}$} \\
\hline Gender & Female & & & \\
\hline & Male & $36(44.40)$ & & \\
\hline Age (years) & $\begin{array}{l}\text { Median (Min-Max) } \\
21(19-25)\end{array}$ & - & - & - \\
\hline Smartphone & $\begin{array}{l}+ \\
-\end{array}$ & $\begin{array}{l}79(97.50) \\
2(2.50)\end{array}$ & $\begin{array}{l}79.50(61.00-101.00) \\
91.00(85.00-97.00)\end{array}$ & $0.110^{\mathrm{a}}$ \\
\hline Tablet Computer & $\begin{array}{l}+ \\
-\end{array}$ & $\begin{array}{l}19(23.50) \\
62(76.50)\end{array}$ & $\begin{array}{l}79.00(62.00-101.00) \\
80.00(61.00-100.00)\end{array}$ & $0.584^{\mathrm{a}}$ \\
\hline Laptop Computer & $\begin{array}{l}+ \\
-\end{array}$ & $\begin{array}{l}69(85.20) \\
12(14.80)\end{array}$ & $\begin{array}{l}80.50(61.00-101.00) \\
76.00(62.00-94.00)\end{array}$ & $0.283^{\mathrm{a}}$ \\
\hline Mobile Internet Package & $\begin{array}{l}+ \\
-\end{array}$ & $\begin{array}{l}80(98.80) \\
1(1.20)\end{array}$ & $\begin{array}{l}80.00(61.00-101.00) \\
-\end{array}$ & - \\
\hline $\begin{array}{l}\text { Mobile Internet Package } \\
\text { Size (GB) }\end{array}$ & $\begin{array}{l}\text { Median (Min-Max) } \\
6(1-25)\end{array}$ & - & - & - \\
\hline Carry a Charger Unit & + & $\begin{array}{l}31(38.30) \\
50(61.70)\end{array}$ & $\begin{array}{l}81.00(62.00-100.00) \\
79.00(61.00-101.00)\end{array}$ & $0.214^{\mathrm{a}}$ \\
\hline Portable Power Supply & $\begin{array}{l}+ \\
-\end{array}$ & $\begin{array}{l}21(25.90) \\
60(74.10)\end{array}$ & $\begin{array}{l}84.00(65.00-100.00) \\
79.00(61.00-101.00)\end{array}$ & $0.019^{\mathrm{a}}$ \\
\hline $\begin{array}{l}\text { Checking Mobile Phone } \\
\text { When Waking Up }\end{array}$ & + & $\begin{array}{l}74(91.40) \\
7(8.60)\end{array}$ & $\begin{array}{l}81.00(61.00-101.00) \\
70.00(62.00-86.00)\end{array}$ & $0.060^{\mathrm{a}}$ \\
\hline $\begin{array}{l}\text { When Waking Up } \\
\text { Checking Mobile Phone }\end{array}$ & $\begin{array}{l}- \\
+\end{array}$ & $\begin{array}{l}7(8.60) \\
79(97.50)\end{array}$ & $\begin{array}{l}70.00(62.00-86.00) \\
80.00(61.00-101.00)\end{array}$ & $0.837^{\mathrm{a}}$ \\
\hline Before Going to Sleep & - & $2(2.50)$ & $80.50(79.00-82.00)$ & \\
\hline Using Internet at Home & $\begin{array}{l}+ \\
-\end{array}$ & $\begin{array}{l}69(85.20) \\
12(14.80)\end{array}$ & $\begin{array}{l}80.50(61.00-101.00) \\
76.50(62.00-100.00)\end{array}$ & $0.434^{\mathrm{a}}$ \\
\hline Using Internet in Student & + & $36(44.40)$ & $77.00(61.00-100.00)$ & $0.083^{\mathrm{a}}$ \\
\hline Dormitory & - & $45(55.60)$ & $80.00(62.00-101.00)$ & \\
\hline Using Internet in School & $\begin{array}{l}+ \\
-\end{array}$ & $\begin{array}{l}64(79.00) \\
17(21.00)\end{array}$ & $\begin{array}{l}80.00(61.00-101.00) \\
79.00(64.00-97.00)\end{array}$ & $0.971^{\mathrm{a}}$ \\
\hline Using Internet With a & + & $77(95.10)$ & $79.50(61.00-101.00)$ & $0.427^{\mathrm{a}}$ \\
\hline Mobile Phone & - & $4(4.90)$ & $82.50(77.00-92.00)$ & \\
\hline Using Internet in Cafes- & + & $50(61.70)$ & $81.00(61.00-101.00)$ & $0.162^{\mathrm{a}}$ \\
\hline Restaurants & - & $31(38.30)$ & $79.00(62.00-100.00)$ & \\
\hline Using Free Public Wi-Fi & + & $38(46.90)$ & $81.00(61.00-101.00)$ & $0.578^{\mathrm{a}}$ \\
\hline Internet & - & $43(53.10)$ & $79.00(62.00-100.00)$ & \\
\hline Average Daily Internet & Median (Min-Max) & - & - & - \\
\hline Usage (hours) & $4.00(1.00-12.00)$ & & & \\
\hline Internet Usage Purposes & Online Shopping & $17(22.10)$ & $82.00(61.00-101.00)$ & $0.233^{\mathrm{b}}$ \\
\hline & $\begin{array}{l}\text { Connecting to Social } \\
\text { Networks }\end{array}$ & $17(22.10)$ & $80.00(62.00-97.00)$ & \\
\hline & Watching Videos & $7(9.10)$ & $81.00(62.00-99.00)$ & \\
\hline & Reading Scientific Articles & $4(5.20)$ & $88.00(82.00-97.00)$ & \\
\hline & Accessing Course Materials & $4(5.20)$ & $85.50(72.00-94.00)$ & \\
\hline & Checking e-Mails & $2(2.60)$ & $88.00(76.00-100.00)$ & \\
\hline & Reading the News & $4(5.20)$ & $81.00(80.00-92.00)$ & \\
\hline & Communicating & $13(16.90)$ & $75.00(62.00-84.00)$ & \\
\hline & Listening to Music & $7(9.10)$ & $79.00(70.00-92.00)$ & \\
\hline & Playing Games & $2(2.60)$ & $71.00(63.00-79.00)$ & \\
\hline Use of Mobile Devices in & Strongly Agreed & $27(35.50)$ & $85.50(64.00-101.00)$ & $<0.001^{\mathrm{b}}$ \\
\hline Dentistry Courses is & Agreed & $39(51.40)$ & $79.00(61.00-94.00)$ & \\
\hline Beneficial & Undecided & $8(10.50)$ & $67.50(62.00-79.00)$ & \\
\hline
\end{tabular}




\begin{tabular}{llll}
\hline Variable & $\boldsymbol{n}(\%)$ & $\begin{array}{l}\text { Total Score } \\
\text { Median (Min-Max) }\end{array}$ & $\boldsymbol{P}$-value \\
\hline & Disagreed & $2(2.60)$ & $73.50(63.00-84.00)$ \\
Strongly Disagreed & - & - \\
\hline
\end{tabular}

$3+=$ Present, - = Absent, ${ }^{\mathrm{a} M a n n-W h i t n e y ~ U ~ T e s t, ~}{ }^{\mathrm{b}}$ Kruskal Wallis Test 


\section{Table 3 (on next page)}

Scores of M-Learning Attitude Scale Factors for Statistically Significant Variables 
1 Table 3. Scores of M-Learning Attitude Scale Factors for Statistically Significant Variables

\begin{tabular}{|c|c|c|c|c|c|c|c|c|c|}
\hline Variable & & $\begin{array}{l}\text { F1 Median } \\
\text { (Min-Max) }\end{array}$ & $P$-value & $\begin{array}{l}\text { F2 Median } \\
\text { (Min-Max) }\end{array}$ & $P$-value & $\begin{array}{l}\text { F3 Median } \\
\text { (Min-Max) }\end{array}$ & $P$-value & $\begin{array}{l}\text { F4 Median } \\
\text { (Min-Max) }\end{array}$ & $P$-value \\
\hline \multirow[t]{2}{*}{ Gender } & Female & $26.00(16.00-35.00)$ & 0.078 & $16.50(5.00-22.00)$ & $0.018 *$ & $20.00(13.00-25.00)$ & 0.414 & $16.00(11.00-20.00)$ & 0.094 \\
\hline & Male & $27.50(20.00-35.00)$ & & $18.50(10.00-25.00)$ & & $21.00(15.00-25.00)$ & & $16.50(12.00-20.00)$ & \\
\hline \multirow{2}{*}{$\begin{array}{l}\text { Portable Power } \\
\text { Supply }\end{array}$} & + & $27.00(23.00-35.00)$ & 0.143 & $18.00(5.00-24.00)$ & 0.179 & $21.00(15.00-25.00)$ & $0.015^{*}$ & $17.00(14.00-20.00)$ & $0.024^{*}$ \\
\hline & - & $26.00(16.00-35.00)$ & & $17.00(10.00-25.00)$ & & $20.00(13.00-25.00)$ & & $16.00(11.00-20.00)$ & \\
\hline \multirow{5}{*}{$\begin{array}{l}\text { Use of mobile } \\
\text { device in } \\
\text { dentistry courses } \\
\text { is beneficial }\end{array}$} & Strongly Agreed & $28.50(22.00-35.00)$ & $0.020 *$ & $19.00(11.00-25.00)$ & $0.009 *$ & $22.00(15.00-25.00)$ & $0.003 *$ & $18.00(14.00-20.00)$ & $<0.001^{*}$ \\
\hline & Agreed & $26.00(20.00-35.00)$ & & $17.00(11.00-22.00)$ & & $20.00(13.00-25.00)$ & & $16.00(12.00-20.00)$ & \\
\hline & Undecided & $23.00(16.00-31.00)$ & & $14.00(10.00-20.00)$ & & $18.00(14.00-21.00)$ & & $14.00(11.00-16.00)$ & \\
\hline & Disagreed & $25.00(22.00-28.00)$ & & $14.50(11.00-18.00)$ & & $18.50(16.00-21.00)$ & & $15.50(14.00-17.00)$ & \\
\hline & $\begin{array}{l}\text { Strongly } \\
\text { Disagreed }\end{array}$ & - & & - & & - & & - & \\
\hline
\end{tabular}

2 F1: Advantages of M-Learning, F2: Limitations in M-Learning, F3: Usability in M-Learning, and F4: Freedom in M-Learning, $+=$ Present, $-=$ Absent, $* P<0.05$ 


\section{Table 4 (on next page)}

Correlations of average daily Internet usage time and age between m-learning attitude scale factors and total score 
1 Table 4. Correlations of average daily Internet usage time and age between m-learning 2 attitude scale factors and total score

\begin{tabular}{llllll}
\hline Factors & F1 & F2 & F3 & F4 & Total Score \\
\hline Average Daily Internet Usage Time & 0.054 & $0.243^{*}$ & 0.072 & 0.094 & 0.138 \\
& $(0.639)$ & $(0.032)$ & $(0.532)$ & $(0.413)$ & $(0.228)$ \\
Age & 0.173 & 0.192 & $0.291^{*}$ & 0.126 & $0.229^{*}$ \\
& $(0.131)$ & $(0.091)$ & $(0.010)$ & $(0.270)$ & $(0.044)$ \\
\hline
\end{tabular}

3 Correlation coefficient $(\mathrm{P}),{ }^{*} P<0.05$ 


\section{Table 5 (on next page)}

Regression model for total score of the m-learning attitude scale according to purposes of Internet usage 
1 Table 5. Regression model for total score of the m-learning attitude scale according to 2 purposes of Internet usage

\begin{tabular}{lllll}
\hline Parameter & $\boldsymbol{\beta}$ & $\mathbf{s e}(\boldsymbol{\beta})$ & $\boldsymbol{P}$-value & $\mathbf{9 5 \%}$ C.I. \\
\hline Online Shopping & 1.419 & 3.609 & 0.695 & -5.791 to 8.629 \\
Connecting to Social Networks & -1.760 & 4.418 & 0.692 & -10.586 to 7.066 \\
Watching Videos & -0.502 & 5.784 & 0.931 & -12.058 to 11.053 \\
Reading Scientific Articles & 9.496 & 7.158 & 0.189 & -4.804 to 23.795 \\
Accessing Course Materials & 9.397 & 7.158 & 0.588 & -10.403 to 18.196 \\
Checking e-Mails & 8.557 & 9.628 & 0.377 & -10.678 to 27.792 \\
Reading the News & 3.266 & 7.158 & 0.650 & -11.033 to 17.565 \\
Communicating & -7.605 & 3.221 & $0.021^{*}$ & -14.025 to -1.185 \\
Listening to Music & -0.858 & 5.784 & 0.883 & -12.413 to 10.698 \\
Playing Games & -12.583 & 9.628 & 0.196 & -31.819 to 6.652 \\
\hline \multicolumn{1}{l}{$\beta$} &
\end{tabular}

